\title{
APPLIED-SCIENCE BASES OF ORGANIZATIONAL-TECHNOLOGICAL AND ECONOMICAL-MANAGERIAL SUPPORT OF BIOSPHERE COMPATIBLE CONSTRUCTION PROJECTS
}

\section{Chernyshev D.}

\section{INTRODUCTION}

The current state and the development trends of economy indicate the presence of important and complex problems caused by the housing stock obsolescence. Increasing problems related to high energy consumption of buildings and to deterioration of microclimate inside stimulate the scientists to look for measures that can effectively reduce energy consumption and solve environmental problems at different levels.

In the established practice of urban planning, the urbanized territories of cities have traditionally been considered as an object opposing to nature, and formation of urban society, virtually during the whole period of its existence, follows the path of extraction of natural resources despite the understanding of the limitations of the natural factor and its depletion. Therefore, the modern practice of urban planning, with insufficient account of the laws of interaction between society and nature, is accompanied by a significant negative anthropogenic impact on the natural environment, and this causes catastrophic consequences for the biosphere and the men, as its component part. An alternative to the established practice of urban planning and common modern ideology of urban territory as not more than a socioeconomic formation that is independent of the environment, can be in an eco-philosophical approach to the problem of relations between the human person and the nature. This approach is reflected in the new concept of innovative policy of urban planning and organization of real estate development on the basis of conceptual and environmental basis of biosphere compatibility - hierarchical system of knowledge, measures and decisions on preservation of human life support environment, maintenance of ecological equilibrium, reduction of negative influence of human activity on the environment, decrease or limitation of consumption of materials and energy sources.

Today, environmental problems are in level with economic problems and are of a general nature, and resolution of those requires the search for new instruments to address the challenge. One of the new instruments is in the 
concept of «green building», this is of great current interest in European countries and is being applied in Ukrainian realities as well.

The green building (Green Construction, Green Buildings) is the practice of construction and operation of buildings with purpose of decrease of the level of energy and material sources during the whole life cycle of the building: from selection of site and up to designing, construction, operation, repair and utilization. Another goal of a green building is to preserve or enhance the quality of the buildings and the comfort of their interior environment. This practice extends and complements the classical building design with the concepts of economy, quality, durability and comfort. New technologies are constantly being improved, and the green building is aimed at reducing the overall impact of the structures on the environment and human health, this is reached due to: - efficient use of energy, water and other resources; - attention to support of health of the residents and to improvement of productivity of the employees; - reduction of wastes, emissions and other impacts on the environment. The main tasks of the green building are: 1) reduction of the cumulative negative impact of construction activity on the environment and human health;2) reduction of the volume of wastes and decrease of other environmental impacts; 3 ) application of environmentally certified materials at construction and in decoration of the buildings; 4) improvement of energy efficiency of the building, minimization of energy consumption, use of alternative energy sources; 5) development of new technologies and creation of modern industrial products; 6) decrease of energy consumption and, accordingly, load on the electrical supply network; 7) integrated reduction of costs for construction and maintenance of buildings. The green building has become not exotic since about 20 years ago. Now, according to environmental standards, housing, shopping centers, officers, educational establishments and production workshops are being built according to ecological standards. Today, there are about 300,000 green constructions in the world. And this, to the fullest extent, gives the basis to consider green building as a global new tendency having long time ago gone out of the status of an experimental direction is rapidly spreading throughout the whole world.

\section{Coordination of the content of general methodological requirements \\ for construction of instruments for organizational and technological support of the projects of biosphere-compatible real estate development}

The concept of green building has originated in the 1970s as a response to the energy crisis and growing public concern about the deterioration of the environment. The need to save energy and to reduce the environmental load has promoted the emergence of green building innovations that continue to evolve till now. The main goal of the green building (green construction, 
ecological construction) is to minimize the negative impact on the environment from the construction industry at all stages by using the best technologies, improving quality and comfort. The main tasks include: 1) reduction of the level of consumption of energy and material resources throughout the whole life cycle of the building (site selection, design, construction, operation, repair, reconstruction, demolition, recycling, utilization); 2) minimization of air, water and soil pollution while optimizing the use of the natural resources; 3 ) improvement of quality and comfort of buildings; 4) application of innovative technologies. The construction industry is responsible for $25 \%$ of harmful emissions, $33 \%$ of greenhouse gases and $50 \%$ of landfill waste. The buildings use $14 \%$ of drinking water and $40 \%$ of energy and raw materials globally. While green building has great potential for the economical and environmental development of the industry, at the background of depletion of natural resources the need for substantial changes in the construction industry in accordance with current market requirements and leading world trends becomes particularly topical. Modern trends of building industry are evolving towards innovative green building technologies that minimize negative effect on the environmental, save natural resources and guard human health. Global trends indicate a quick increase in the number of green building projects in developing countries: Brazil -6 times, China -5 times, Saudi Arabia -4 times, and Mexico, Colombia, South Africa and India expect a twofold increase in green initiatives. Why should Ukrainians live less well? Implementation of green projects contributes to the energy and economic independence of Ukraine. The leading global investors favor green buildings, and innovations and increase of energy efficiency provide the Ukraine's economic development. But the most important thing is that green building has a positive effect on the social well-being of nation, improves the comfort, safety and health of the population. Is Ukraine ready for large-scale implementation of green building? Undoubtedly - yes! Green building is focused first of all on people. It is for those living and working in green buildings, designing and building the buildings, visiting the green buildings and using the infrastructure of the buildings. While the green building supporters are convincing the construction companies of its economic viability and energy efficiency, the ordinary citizens have no doubt about the benefits of green buildings. People spend more than $90 \%$ of their lives in buildings, with indoor pollution indicators being 2-5 times compared to the outside situation and, by the WHO estimates, $12.7 \%$ of deaths can be avoided if air quality in buildings is improved. Green standards carefully monitor the indoor air quality, the level of volatile organic compounds and other pollutants, with those of microbiological origin included. The Building Research Establishment, a British research center, provides dramatic 
statistics on the effect of low-quality housing on human health. The cost indicators for eliminating the negative effects of poor housing are ranked as fourth after such dangerous health risks as alcohol, smoking and obesity. The green building standards not only minimize the environmental impact at all the stages of the construction process, but are also focused on improving the health, safety and comfort of people. Green building safety standards include the reliability of building structures, inclusive and easily understood design of construction projects, operational risk management, safety of motion over the object, energy-efficient lighting of premises and surrounding areas. Living and working in green buildings is comfortable, since the green building standards include clear requirements for provision of ergonomics and convenience. The green building standards control the optimum mode of lighting, thermal comfort correlated with seasonal temperatures, ventilation and conditioning with regard to natural potential, acoustic comfort. Clear planning of green buildings provides convenient infrastructure, accessibility by transport and comfort of motion over the object. Special attention is paid to the attractive aesthetics of green buildings, because the constructed environment substantially affects the physical and mental state of people. In a green office it is better to work, and you want to stay longer, thus the level of performance is increased by $8-11 \%$ due to reduction of the illness frequency and to improvement of working conditions. In the areas with beautiful architecture, people feel satisfied, calm and happy, while ecologically friendly aesthetics and harmonious natural design create the conditions for inspiration and success. Application of green certification increases the financial characteristics for investors, lease takers and owners and encourages innovations in the construction sector. Dozens of green building certification systems are now in place, though the first were the British, who as long ago as in 1921 have established the scientific-research center for the real estate development, the Building Research Establishment (BRE), to take care of the development of the construction industry in in direction of decrease of negative impact on the environment. And just there in the 1990 the first system for certification by the green building standards has been developed - the Building Research Establishment Environmental Assessment Method (BREEAM) ${ }^{1}$. It is an independent and impartial method of environmental assessment of construction projects, infrastructure and buildings. It is currently used in 83 countries over the world and covers $80 \%$ of the registered green buildings in Europe. The BREEAM standards are scientifically based and are adapted to national building standards and local climatic conditions. BREEAM remains the world's first leading method for assessing the

\footnotetext{
${ }^{1}$ https://www.breeam.com/
} 
sustainability of general projects, infrastructure and buildings for a number of life-cycle stages: new construction, operation and reconstruction. In addition, the British green building system has a developed structure, so, the BRE Trust is a charity organization that supports the scientific and educational activities in directions of improvement of the built environment since 1997. Within this structure there functions the BRE Academy, a top ranked world leader in ecological building education for professionals on the basis of fundamental knowledge in the field of construction, architecture, urban planning, engineering and other areas of the construction industry. Despite the widespread use of BREEAM worldwide, there are currently only seven BREEAM licensed appraisers and the same number of registered green building projects in Ukraine, and only four buildings certified by the BREEAM standards. Large-scale implementation of green building requires the involvement of State structures. Previously, the green building has been associated with high costs, but the experience of developed countries shows that due to the State regulation a new market is emerging. More service providers appear, and at accumulation of critical mass this leads to lower prices. The State should formulate a goal, define a plan to achieve that goal and develop mechanisms to implement the plan. The government agencies should work closely with all the key participants of the construction sector to implement the green building practices, and then the green building in Ukraine will become not a luxury business but it will become a usual business model. Development of a sustainable urban environment is the result of the State policy and changes in public awareness. At presence of political will and a stimulating regulatory framework, green construction can go from underground in the mainstream.

Real estate development is an area of economic activity that has the greatest potential for energy saving, and as it is one of the main consumers of energy resources it has recently faced with the problem of the most rational use of those, at the stage of production of various building materials and of operation of completed real estate objects for different functional purposes as well.

In our opinion, the concept of green building is a combination of components of building ecology, namely the urban ecology, bio-positive construction, environmental reliability and safety, energy-active and energysaving buildings, resources, non-waste production, waste treatment and ecological monitoring.

According to statistics provided by the Ecological Building Council, the buildings around the world use today about $40 \%$ of all the primary energy consumed, $67 \%$ of all electricity, $40 \%$ of all the raw materials and $14 \%$ of all drinking water and generate $35 \%$ of all the carbon dioxide emissions and 
up to $50 \%$ of all solid wastes ${ }^{2}$. In this regard, the concept of «green» construction or, in other words, of ecological construction aimed at reducing the level of consumption of energy and material resources, as well as reducing the harmful effect of construction activity on human health and the environment has come to existence ${ }^{3}$.

Currently, the scientists are studying and providing several terms that are identical, namely, «green building», «ecological construction», «sustainable construction», «eco-development». However, in recent years, the term «green building» has become more widespread. The wording «green building» originated in the the United States and European countries as early as the 1970s. The cheapness and inexhaustibility of energy reserves led to a rather wasteful nature of use of those, this has most clearly manifested itself in construction, as the result during fifteen years (from 1965 to 1980) the world energy consumption has become, on average, 1.7 times higher, and the energy consumption for construction and operation of buildings and structures (excluding consumption for production) in the 1970s began to account for about half of the total energy consumption in the most of developed countries: in Germany, in Netherlands - 39\%, Ireland - 46\%, the United Kingdom - $48 \%$, Denmark - $50 \%$. In addition, more than $90 \%$ of those volumes, according to the EEC (European Economic Commission) data, are directly related to operation of buildings and structures ${ }^{4}$. The gradual but steady depletion of the explored fields of traditional energy sources have made need in the development of new ones, mainly located in regions with hard climate, and this has lead to increase in the specific cost of fuel production by more than 3 times. Due to those circumstances, the significant rise in world prices for traditional energy carriers, which occurred in the late 1970s, called into question the feasibility of construction in general: the cost of maintaining buildings has began to exceed the revenues from use of those. In 1975, the first demonstration buildings with high energy efficiency appeared. So, it can be asserted that the green building has emerged not long ago, but it is growing rapidly and becoming more and more popular all over the world. As a result there are new technologies; and the industrial activities of people have led to environmental degradation. Increasing levels of pollution of environment all over the world, global warming and the necessity of more economical use of the planet's energy resources have become the major factors for development of green building.

\footnotetext{
${ }^{2}$ Офіційний сайт компанії Life House Building. - Режим доступу: http://lhb.com.ua/

${ }^{3}$ Офіційний сайт компанії Еcopan. - Режим доступу: https://ecopanua.com/

${ }^{4}$ Orlovs'ka Y. Green investments' programs as an element of industry's international mpetitiveness (on example of construction industry) / Y. Orlovs'ka, O. Kvaktun, V. Chala, M. Vovk // Marketing and Management of Innovations. - 2017. - № 3. C. 366 - 377.
} 
Green building is also understood as construction and operation of buildings with lower consumption of energy and materials throughout the whole life cycle of a building. In our opinion, the most appropriate is the definition given by the National Agency for Sustainable Development, according to which the green building is a practice of construction and operation of buildings, the purpose of which is to decrease the level of consumption of energy and material resources throughout the whole life cycle of the building, to support or improve the quality of buildings and the comfort their indoor environment. The major concern of this approach is to reduce the overall impact of the building on the environment and human health. This practice extends and complements the classical construction design with the concepts of economy, utility, durability and comfort. From this definition, we consider it necessary to point out the main tasks of green building. So, in our opinion, the main tasks of green building are:

- to increase the efficiency of use of natural and renewable resources (sun, wind, water);

- to decrease emission to atmosphere of gases with formation of the greenhouse effect;

-to increase the share of renewable energy sources (sun, wind, water) through their introduction into technological process and use in the operation and maintenance of residential green buildings;

- to reduce the negative effect (over the whole life cycle of a building) on human health while staying in a dwelling house through application of the latest, energy sawing, natural and safe materials;

- to reduce the loads on power networks through introduction and application of renewable energy sources;

- to reduce the operating expenditures.

Having pointed out the green building goals, the authors consider it to be appropriate to focus on the benefits and purposes of implementation of green building pursued by different businesses entities. For example, the benefit of architects is first of all in increasing their competence and high appraisal of design projects, and therefore increase of the salaries; as to contractors and developer companies, the benefit of introduction and building green homes is in increase in orders for construction objects and rather quick sale of apartments in green buildings. The benefits of manufacturers of building materials are in increasing profits, increasing competitiveness at the national market of building materials and entering new markets. The State also benefits from introduction of green building, this is in meeting the environmental investment commitments (Kyoto Protocol), reduction of unemployment level and creation of new jobs. For developers, their benefits include attracting additional investments in the country and the industry. The landlords' benefits are to increase the rental rates and the level of occupancy 
after the house is put into operation. The benefit of the population from green building is in reduction.

\section{Formation of methodical-analytical system of indicators for provision of biosphere compatibility at preparation and organization of construction}

The green construction is realized as «Green Buildings». A green building, or an environmentally sustainable building, is the result of a design philosophy that seeks to: increase the efficiency of use of scanty resources (land, energy, heat and cold, water and materials); to reduce the adverse impact on human health and to minimize the negative effect on the environment throughout the whole life cycle of the building, through better location, design, construction, management, operation and further demolition ${ }^{1}$. It should be noted that the «green building», «green buildings» is a practice of constructing and operating buildings with the purpose, first of all, to reduce the consumption of energy and material resources throughout the whole life cycle of the building: from the site selection and further at designing, during construction, operation, repair and demolition. Another important goal of green building is to maintain or enhance the quality of buildings and the comfort of their indoor environment. These statements, in our opinion, substantially complement the standard, conventional real estate development with concepts like economy, durability and comfort.

Though the new green building construction technologies are constantly being changed and improved, the main goals of green buildings are:

- reduction the overall impact of the building on the environment and human health that can be achieved through the efficient use of electric energy, water and other resources;

- reduction of wastes, emissions and other impacts on the environment. In addition, green buildings are completely cost-effective and do not require high maintenance costs, this saves money ${ }^{2}$.

The definition of «green building» covers all the phases of the life cycle of a building, including design, construction, operation and demolition (dismantling). The green buildings save resources by using energy, water and materials more efficiently throughout their life cycle that also includes the initial phase of construction. Most scientists compare the environmental stresses generated throughout the whole life cycle by constructing bimetallic and hollow flooring systems for commercial buildings with application of mixed life cycle assessment method. The studies cover the stages of material extraction and construction and include the detailed assessment of the direct effect and the effect of material supply chain as well. A number of results are obtained, those are presented in several categories for comparative evaluation. Those include the energy consumption, emission of carbon 
dioxide $\left(\mathrm{CO}_{2}\right)$, carbon monoxide $(\mathrm{CO})$, nitrogen dioxide $\left(\mathrm{NO}_{2}\right)$, sulfur dioxide $\left(\mathrm{SO}_{2}\right)$, fine particulate airborne matter $\left(\mathrm{PM}_{10}\right)$ and volatile organic matter. The other categories include solid wastes and release of liquids.

Hereinafter, the author considers it necessary to analyze separately the main types of green building. There are nine types of nesting architectural and planning solutions in the concept of green housing development:

- The energy-efficient building with low or zero energy consumption (zero-energy building). This is, first of all, a building with high energy efficiency that can produce power through renewable energy sources. If the building produces less energy than it is needed for consumption, the building is called a near zero-energy building. The advantage of zero energy buildings is that they do not use fossil fuels and get all the energy they need through introduction of renewable energy sources.

- A passive building is a building that uses energy-saving building materials and renewable energy sources. It can also be said that it is an ecohouse with heat generated by passive method, with application of available internal heat sources only, for instance solar energy that goes through the windows. The main advantage of a passive house is that there continually circulates clean and warm fresh air, and the walls and floor are also warm all the time.

1. Bioclimatic architecture is a building with pronounced use of glazed spaces and with natural light. Bioclimatic architecture is a building constructed with account of the climate of the region that has to provide required comfortable living conditions with minimal energy consumption and with use of environmentally friendly sources of energy like sun, wind, water promoting saving of energy for heating, cooling and lighting the building.

2. An intelligent or smart building is a building where the flows of light and heat in premises and structures are optimized. An intelligent, or a smart building (smart home, digital house) is a residential house or premises of building for commercial purposes with high-quality support systems and an operational multi-room. Multi-room is a system by means of which all the electrical devices of the building can be functionally interconnected, with possibility of centralized control from a remote display.

3. A high-tech building is a building with state-of-the-art solutions in architecture in terms of constructions and materials.

4. A healthy building that prioritizes ecologically friendly natural building materials.

5. A life-support building with zero waste characteristic and zero characteristic of energy consumption.

6. Eco-low-tech is a building that is built with use of local natural materials like wood, clay, straw and so forth. 
7. Eco-futurism. A completely new trend in the construction of buildings, the main idea of which is that the new artificial substances will be non-toxic and will become integral parts of waste-free economic cycles. Part of the elements of the house after the onset of its physical deterioration and moral depreciation will return to the soil and dissolve in it, and the other part can be re-incorporated into new production chains.

Thus, having analyzed the types of green housing construction, we can conclude that the construction of green buildings in the sector of housing development is aimed at improving the energy efficiency, improving living conditions through introduction of ecologically friendly materials to the technological process of construction. That is, the construction of green buildings is first of all aimed at meeting the needs of society.

Therefore, the main economic advantages at the implementation of green building and green technologies are the reduction of the prime cost of construction, increase of consumer demand for green houses by $35 \%$ compared to conventional ones. Besides that, application of green construction leads to reduction in operating costs by $13.6 \%$ compared to conventional buildings. Economic effects:

- Increased current net income (for example, a $3 \%$ premium by average rate of lease agreement) and property asset value (for instance, $10 \%$ premium for commercial value) may result in lower financial and insurance costs;

- Most «green buildings» are more expensive than conventional ones by no more than $4 \%$, and in the near future the use of green technologies will become the most effective means of reducing the prime cost of construction;

- Green construction leads to increase in consumer demand for green buildings (by $35 \%$ ) and the market demand (by $33 \%$ );

- Reduction of operating costs by $13.6 \%$ for new construction and by $8.5 \%$ for an existing building;

- More than $50 \%$ of hot water needed for the household purposes that is heated by solar collectors, with the excess re-directed to the heating system. The required volume of drinking water is decreased by $26,000 \mathrm{~m}^{3}$ per year;

- Recycling and reuse of $98 \%$ of the waste left over at reconstruction of the old building. More than 30 tons of such unnecessary materials are used as building elements for $15,000 \mathrm{~m}^{2}$ of other buildings.

When constructing a green building, it is possible to use the wastes from reconstruction of the old building, this leads to savings on building materials.

Among the environmental benefits it should be noted that at construction of a green building made of wood, it is possible to reduce the $\mathrm{CO}_{2}$ emission by 0.8 tonnes. 
The social benefits should also be addressed, with emphasizing the following ones: in a green building rate of work is much higher compared to a conventional building, and it is possible to reduce the cost of purchasing medicines through construction of green houses.

It should be noted that as green buildings there can be not only newly built buildings. Virtually any building can be upgraded, with implementation of environmentally friendly technologies that optimize energy consumption and reduce the negative environmental impact.

When designing a green building project, the environmental impact of the building is also taken into account: how harmoniously it fits the natural landscape, thus making an attempt to minimize the environmental impact of the construction process. Today, the share of green buildings in the total number of new buildings in the EU countries has reached 20, and the number of such buildings in developed countries is constantly increasing. As for Ukraine, according to experts, the country now has all the preconditions and conditions for the development of green building.

The concept of green building views the real estate object not only as a construction product, i.e. as completed in construction and put into operation buildings and structures, but as a place for existence of a human person, i.e. the whole set of factors of the building and its infrastructure that determine the living conditions. At that, most scientific and methodological and regulatory sources define the green building as an approach to the design, construction and operation of buildings, a number of solutions, measures, with cover the materials and equipment aimed at energy efficiency and resource efficiency, safety for human health, comfort and environmental friendliness. The main requirements for such objects throughout the whole life cycle are the rational use of renewable resources (energy of the earth, water, wind, etc.), minimization of the negative impact on the natural environment, comfortable living conditions for people. We detail each of the highlighted groups of problems.

Environmental problems: depletion of natural resource potential of territories; pollution of environment (lithosphere, atmosphere, hydrosphere, etc.); increase of man-caused load on the environment as the result of intensification of production; finiteness of non-renewable natural resources; depletion of resources; inability to predict externalities; global climate change; impossibility of assimilation processes; reduction of biodiversity; the process of degradation of environmental components that has no retroactive effect; accumulation of significant amounts of industrial and solid household wastes; the emergence of ozone holes (greenhouse effect, global warming) and the like.

Economic problems: lack of adequate financing of environmental measures by economic entities, although this is the largest share of sources 
of financing the environmental measures; not enough use of innovative potential of enterprises; absence of widespread system of environmental management at enterprises; moral and physical deterioration of fixed assets; large amount of industrial wastes; lack of motivation for environmental activities; poor product quality; absence of a well-established system for processing production wastes; extremely poor level of development of own production; rather narrow focusing in specialization of regions on the production of industrial, consumer and agricultural products, etc.

Political problems: unstable political situation in the country that has a negative impact on all spheres of life; the lack of a clear environmental policy of the State; absence of a political lobby for proper financing of problematic subformations, since $91 \%$ are financed from own funds, and only the rest ones - from the State and local budgets.

Technological problems: excessive scale of production potential of the fuel and energy complex and heavy industry; a significant lag behind the world level of technical indicators and resources used in the national economy; differentiation of economic entities by the technical level of the production fund, the conditions for providing resources and sales of products; gaps in the technical level, in the quality of machines, equipment and other resources involved in integrated chains of production and technological links.

Market problems: lack of market of green products; distribution of products dangerous for the health of population; absence of market mechanisms for regulation of environmentally safe and cost-effective economic activity; low level of competitiveness of domestic enterprises; insufficient level of solvent demand for ecologically safe products.

Socio-demographic problems: deterioration of the quality of life of population, deterioration of health, low level of income of citizens, emergence of incurable diseases and spread of those, propagation of genetically modified food products, lack of a system of formation of environmental responsibility and environmental education; change of cultural values, moral and ethical degradation of society, rapid pace of urbanization, untimely and incomplete informing of population on the whole range of problems that are to be solved on the way to sustainable development of society, problems of activating public activity, etc.

Institutional issues: lack of regulatory support for sustainable development at both, the national and the regional levels; the imperfection of the current state of legislation on the transition to sustainable development and the practice of law enforcement in the field of nature management and protection of environment; insufficient motivation of environmental protection activities by the State and the regional governments; lack of a strategy for transition to sustainable development; absence of an adequate 
number of relevant institutions to address the above issues; a poor role of environmentally-oriented organizations in public life.

In the process of development of the organizational concept of construction process, the main task is to build an organizational and technological model that takes into account the structure of construction flows and the algorithms of functioning and interaction of those. Both tasks are initially formed on the basis of the design estimation documentation.

However, usually, when designing the organization of operation of complex construction systems, it is not possible to find a clear unambiguous solution. There are always several alternative solutions to form up the system of building and installation works (BIW) and special works, at that each of those solutions provides the ability of substantial modifications, and in the process of construction at can be radically changed, adjusted in an operational manner.

The cost and duration of the works depend on the method of organization of construction, technology of performance of BIW, and the choice of those is influenced by the adopted architectural and planning, constructional and engineering solutions.

Referring to ${ }^{5}$, the determination of the duration of construction depends on the available initial data, namely:

- the volume of construction work, expenses for labor, material and technical resources required to perform construction work;

- the master plan solution;

- three-dimensional design and structural solutions for the project ;

- general organizational and technological schedules for construction of the basic building object and the facilities for utility and service purposes, energy economy, transport and communication, external networks;

- the list, the volumes and duration of works carried out during the preparatory period;

- the construction conditions (building density, engineering and geological conditions, etc.);

- conditions for financing the construction;

- information on the terms of delivery and transportation from enterprises - suppliers of building structures of finished products, materials and equipment (possible terms, frequency, volumes and completeness of delivery, etc.);

- information on provision of the construction site with labor resources (qualitative and quantitative composition, average productivity of workers

\footnotetext{
${ }^{5}$ Визначення тривалості будівництва об'єктів: ДСТУ Б А.3.1-22:2013 / Мінрегіонбуд України. - Вид. офіц. - Чинний від 2014-01-01. - Київ, 2014. - 30 с. - (Національний стандарт України)
} 
by type of work), construction machines and mechanisms (list, number, productivity), etc.

It should be noted that the estimated cost of construction has to take into account the change in the value of money over time, so in the cost characteristics of the project, at the design stage, application of the hereinafter contained is to be foreseen: the inflation index, determined by the State Statistics Committee of Ukraine; the index of change in the cost of construction and installation works determined by the Ministry of Regional Development of Ukraine; as well as the coefficient taking into account the regional construction conditions determined by the Ministry of Regional Development of Ukraine ${ }^{6}$.

Nowadays, the characteristics of cost and duration of construction determined at the planning stage substantially differ from the real ones, in particular the research ${ }^{7}$ provides up-to-date data on construction of a number of objects from which it follows that the larger the area and, respectively, the longer in time the term of construction is, larger is the the actual deviation of the real terms of construction from the planned ones, for various reasons, in some cases by $50 \ldots 100 \%$, being a problem for ensuring the reliable implementation of construction projects by construction organizations.

At determining the factors that have a determinative influence on the performance characteristics of organizational and technological construction solutions, V.I. Bolshchakov, T.S. Kravchunovska, S.P. Bronevitsky have identified the main factors affecting the increase in the cost of construction ${ }^{8}$ :

- the low level of organization of the construction process, logistics and calculations in the construction, this causes losses because of defects and idle time in amount of up to $12-15 \%$ of the construction cost;

- the design shortcomings, poor quality of design estimation documentation;

- high expenses for the engineering preparation of the territories, imperfection of the rules for determining the costs for connection to the engineering networks and main sources of water, electric power, gas;

${ }^{6}$ Организационно-технологическая и экономическая надежность в строительстве / В. Р. Млодецкий, Р. Б. Тян, В. В. Попова, А. А. Мартыш. - Днепропетровск : Наука и образование, 2013. - 193 с.

7 Большаков В. І. Фактори, що здійснюють визначальний вплив на показники ефективності організаційно-технологічних рішень будівництва доступного житла [Електронний ресурс] / В. І. Большаков, Т. С. Кравчуновська, С. П. Броневицький // Вісник Придніпровської державної академії будівництва та архітектури. - 2016. - № 5. C. 61-70. - Режим доступу: http://nbuv.gov.ua/UJRN/Vpabia_2016_5_10

8 Большаков В. I. Фактори, що здійснюють визначальний вплив на показники ефективності організаційно-технологічних рішень будівництва доступного житла [Електронний ресурс] / В. І. Большаков, Т. С. Кравчуновська, С. П. Броневицький // Вісник Придніпровської державної академії будівництва та архітектури. - 2016. - № 5. C. 61-70. - Режим доступу: http://nbuv.gov.ua/UJRN/Vpabia_2016_5_10 
- growth of cost of building materials, products and structures;

- frequent change of contractors, imperfection of competition procedures for selection of the contractors;

- frequent shutdowns of the production cycle and conservation of facilities due to lack of financing (construction renewal costs result in losses of up to $10 \%$ of the estimated cost).

To the factors that will definitely affect the cost and duration of construction, the scientists ${ }^{9}$ attribute the architectural and planning decisions, structural systems of buildings, material of supporting structures, the level of engineering support of the building, the energy efficiency class of the building.

The degree of influence of the factors on the cost and duration of construction is given in Table. 1 .

Table 1

The main characteristics of evaluation and identification

of organizational and technological reliability in the projects

of biosphere compatible construction

\begin{tabular}{|c|c|c|c|}
\hline \multirow[b]{2}{*}{ No. } & \multirow[b]{2}{*}{ Factor } & \multicolumn{2}{|c|}{ Degree of effect on * } \\
\hline & & $\begin{array}{c}\text { Cost of } \\
\text { construction }\end{array}$ & $\begin{array}{l}\text { Duration of } \\
\text { construction }\end{array}$ \\
\hline 1. & $\begin{array}{l}\text { Urban features and investment } \\
\text { attractiveness of urban areas }\end{array}$ & 3 & 1 \\
\hline 2. & $\begin{array}{l}\text { Storey number (multifunctionality) of the } \\
\text { building }\end{array}$ & 3 & 3 \\
\hline 3. & Total area of the building & 3 & 3 \\
\hline 4. & Construction volume of the building & 3 & 3 \\
\hline 5. & Methods of organization of construction & 3 & 3 \\
\hline 6. & Confinement of the construction site & 3 & 3 \\
\hline 7. & $\begin{array}{l}\text { Reliability of organizational and technological } \\
\text { solutions }\end{array}$ & 3 & 2 \\
\hline 8. & Commonality of structures & 2 & 3 \\
\hline 9. & The degree of prefabrication of buildings & 2 & 3 \\
\hline 10. & $\begin{array}{l}\text { Availability of storage and structure assemblage } \\
\text { areas }\end{array}$ & 1 & 1 \\
\hline 11. & Adaptability of design solutions & 3 & 3 \\
\hline 12. & Durability of the building & 1 & 1 \\
\hline 13. & Productivity of work & 1 & 2 \\
\hline 14. & Methods for staff motivation & 1 & 1 \\
\hline
\end{tabular}

*1-Low level of effect, 2 - moderate, 3 - high level.

${ }^{9}$ Стан реалізації ключових завдань Державного агентства 3 енергоефективності та енергозбереження України у 2015 році [Електронний ресурс]. - Режим доступу: http://saee.gov.ua/sites/default/files/Presentation_2015.pdf 
Despite the obvious benefits, the development of green building in Ukraine is quite problematic. The green building market is represented by single private companies. The best known among those are: LifeHouseBuilding (500 projects are developed, more than 50 structures are built in Dnipro, Kyiv, Kharkiv, Lviv, Vinnytsia region, Kamiansk, Zaporizhia and Crimea ${ }^{2}$ ), Ecopan (more than 500 projects are implemented in Ukraine and Europe $^{3}$ ). The scale of construction within the State is negligible. The main reason for this is in high initial expenses and the unpredictable commercial benefits of such investments. The cost of ecological construction exceeds the cost of traditional real estate development by $30 \%$. In addition, corruption and unorganized information activities on scientific and technical proposals hinders the development of the sector at the internal level ${ }^{9}$. This problem can be addressed through appropriate State policy. However, no tools have been developed till now to encourage the new green construction. The main normative legal acts related to this field are: the Law of Ukraine «On Energy Efficiency of Buildings» dated July $1,2019^{10}$, the Law of Ukraine «On Amendments to Some Laws of Ukraine on Ensuring Competitive Conditions for Production of Electricity from Alternative Energy Sources» dated May 25, 2019, No. 2712-VIII ${ }^{11}$, the Law of Ukraine «On the Environmental Impact Assessment» dated May 23, $2017^{12}$. Though there is no systematic vision of the State as to promoting ecological construction. The situation is somewhat better with regard to the ecological modernization of energy-intensive multi-storey buildings. Since October 2014, the Government «Warm Credit» Program has been in operation; in 2015, 80,000 loans were provided, in amount of UAH 1.3 billion, and of those, UAH 302 million is reimbursed ${ }^{9}$. However, this instrument is mainly for the household sector, without affecting the large scale of construction activity. The State agencies are just beginning their activities in the field of «green building». The State Agency for Energy Efficiency and Energy Saving of Ukraine, in cooperation with European partners, has implemented four projects of «green building» on thermal modernization of equipment ${ }^{13}$. On May 30, 2017, the Committee on Green

\footnotetext{
${ }^{10}$ Про енергетичну ефективність будівель: Закон України від 1 липня 2019 року № 33 [Електронний ресурс]. - Режим доступу: https://zakon.rada.gov.ua/laws/show/2118-19

${ }^{11}$ Про внесення змін до деяких законів України щодо забезпечення конкурентних умов виробництва електричної енергії з альтернативних джерел енергії: Закон України від 25 травня 2019 року № 2712-VIII [Електронний ресурс]. - Режим доступу: https://zakon.rada.gov.ua/laws/show/2712-viii

12 Про оцінку впливу на довкілля: Закон України від 23 травня 2017 року № 29 [Електронний ресурс]. - Режим доступу: https: https://zakon.rada.gov.ua/laws/show/2059-19

13 Реалізовані проекти Державного агентства 3 енергоефективності та енергозбереження України [Електронний ресурс]. - Режим доступу: http://saee.gov.ua/ uk/business/realizovaniproekty
} 
Ecological Construction was established at the Construction Chamber of Ukraine. However, on the official website of the institution ${ }^{14}$ there is no information regarding the committee's powers. Thus, the "green building» in Ukraine is at an early stage of development, and its prospects will depend on the effectiveness of the State support for the sector. The State institutions face the key challenges, those are are in elaboration of strategic documents on green building development and provision of State support instruments (benefits for companies operating in this field and attraction of international assistance), in conducting an information campaign on promoting the benefits of green building in Ukraine, preparing and implementing a system of standards in the field of ecological construction.

The main tool for implementing the principles of green building in real estate projects is the so-called green certification system. The «Green certification» systems are characterized by the following: - assessment of the entire life cycle of a building, not just the design and construction part; application of a wide range of different criteria evaluating the location of the site, the design and construction technologies applied, the use of the renewable energy sources, dismantling technology, etc.; - certification is not a single action, but it is a process that accompanies the design and construction of the object. There are several independent certification systems in green building. Most widespread: - BREEAM (Building Research Establishment's Environmental Assessment Method, UK), since 1990 about 558,000 buildings in 50 countries have been certified. The previous LEED certification was obtained by the Astarta Business Center in Kyiv and the Optima in Lviv; - LEED (Leadership in Energy and Environmental Design, USA), since 2000, has certified about 90,000 buildings. In Ukraine, under this system the US Embassy building and Shell office (in Toronto Business Center) are certified; - DGNB (Deutsche Gesellschaft für Nachhaltiges Bauen, Germany), since 2009, approximately 1100 buildings have been certified. As a 2nd generation rating system, it provides the most comprehensive assessment of a building from the point of view of «sustainable development». The State does not yet have programs for support of this direction that would meet the global trends of the regulatory framework. However, there is a positive experience in supporting at the State level of the direction of renewable power generation, this has led to substantial progress in this area («green» tariff law).

In 2013, the public organization «Green Building Council» (UaGBC) was registered in Ukraine, with the main objective of bringing together organizations and professionals who adhere in their activity to the principles

\footnotetext{
14 Повноваження Комітетів Будівельної палати України [Електронний ресурс]. Режим доступу: http://budpalata.com.ua/category/povnovagenya-komitets
} 
of green building. The main priorities of the Council are: - to amend the Ukrainian legislation, for development of green direction in the industry of real estate development; - certification of buildings in accordance with «green» standards; - dissemination and promotion of the «green» building ideas; - introduction of international standards of green building in Ukraine. The Council brings together the companies, organizations and individuals interested in application of the principles of sustainable development when implementing the real estate projects, projects of the energy generating industry and of related fields. Ukraine has become a member of the World Green Building Council since 2016. Now, the main tasks for the country are: - to develop a regional network of offices; - to establish a system of design, construction and evaluation according to the criteria of green building. However, the development of green building in Ukraine is possible only under the following conditions:

1. Upgrading of the level of qualification of specialists.

2. Introduction of the "Green Building» course into the educational process.

3. Design, construction and operation by the green building standards.

4. Development of scientific support for this standard.

5. Development of production and operation of environmentally friendly equipment and materials.

6. Introduction of taxes on building materials, except of environmentally friendly.

7. Increase of the demand for green buildings.

8. Increase of environmental awareness of population.

9. Development of State building codes for the design, construction and operation of green buildings.

10. Design of buildings with low level of energy consumption.

From the point of view of biosphere compatibility, construction development must ensure the integrity of biological and physical natural systems. Of particular importance is the viability of the ecosystems on which the global stability of the entire biosphere depends. Moreover, the concept of «natural» systems and habitats can be understood broadly, with the created by human person environments, like the urban one, included. The focus is on maintaining the self-regeneration ability and capacity of such systems to dynamically adapt to changes, rather than keeping those in some «perfect» static state. Degradation of natural resources, pollution of environment and loss of biological diversity reduce the ability of ecological systems to recover. Construction is one of the powerful anthropogenic factors for environmental impact. The anthropogenic effect of construction is diverse in its nature and takes place at all the stages of the construction activity - from 
the extraction and production of building materials, construction of objects, operation of those and with the end at dismantling of worn buildings. It is proposed to base the development of a methodology for assessing the biosphere compatibility of architectural objects on the ideas laid out to calculate the indicator of the level of implementation of the functions of biosphere compatible settlement. The architectural object biosphere compatibility index $\mathrm{Zbs}$ is proposed to be calculated by the formula:

$$
\mathrm{Zbs}=\Sigma\left(Z i * m_{i}\right)=Z \mathrm{M}^{*} \boldsymbol{m} \mathrm{M}+Z \mathrm{~b}^{*} \boldsymbol{m} \mathrm{5},+Z Ж m Ж+Z Д * m Д
$$

where

ZM - the index of biosphere compatibility for plant-manufactured materials and products of which the building is constructed;

Z6 - the index of biosphere compatibility for the phase of construction of the building;

$Z$ Z - the index of biosphere compatibility for the stage of the life cycle (operation) of the building;

$\boldsymbol{Z}$ Д - the index of biosphere compatibility for the phase of demolition and utilization of the materials and structures of which the building was constructed;

$\mathbf{m}_{\mathbf{i}}=\{\boldsymbol{m} \mathbf{M} ; \boldsymbol{m} \mathbf{5} ; \boldsymbol{m}$ Д $\}-$ the weight coefficients of the respective indices.

The accuracy of the complex evaluation is enhanced when the weight coefficients of the of the property indices are taken into account. At account of the weighting factors, the question of determination of those arises. There are computational methods for determining those coefficients, though the methods are imperfect and often enough produce inconsistent results. At the present stage, it is better to use an expert method for determining the weight factors that is based on the application of generalized experience and intuition of expert specialists. Among the expert methods, the most suitable for determining the weighting factors are: preference method, rank method, pairwise comparison method, etc. The most common method is the method of preference, it is realized as follows: the experts assign the numbers to the weights of all the characteristics in order of preferences of those, so that the most important one is given the weight of number 1, the next one by importance - number 2, and so on. Then the arithmetic mean value is calculated by each characteristic, with account of the opinions of all experts. With the ranking method, the experts evaluate the importance of each characteristic on the grounds of a predefined scale of relative importance in 
the range from 0 to 1 . The weighting factors $m i$ are found on the basis on the estimates assigned by all the experts for each characteristics in their totality, with application of ranks. According to International Standards (EN 1990:2001 / Eurocode - Basis of structural design), the reliability of construction objects - in a single cycle «preparation-constructionoperation» - is considered as a combination of safety, suitability for normal operation and durability. Safety is considered as an attribute of a construction object to maintain its suitability for operation during a prescribed period without potential threat to human life and health.

In the established practice of urban planning, the urbanized territories of cities have traditionally been considered as an object opposing to nature, and the formation of urbanized society, practically for the whole period of its existence, folows the way of extraction of natural resources despite the understanding of the limitations of the natural factor and its depletion. Therefore, the modern practice of urban planning, with insufficient account of the laws of interaction between the society and the nature, is accompanied by a significant negative anthropogenic effect on the natural environment, this causes catastrophic consequences for the biosphere and the human being as a part of it. As an alternative to the established practice of urban planning and the deep-rooted modern outlook on the city as a socio-economic formation only, independent of the natural environment, there can be the eco-philosophical approach to the problem of relations between the humans and the nature. This approach is reflected in the new concept of innovative policy of urban planning and organization of construction activity on the basis of conceptual and environmental basis of biosphere compatibility hierarchic system of knowledge, measures and decisions on preservation of the life support environment, maintenance of ecological equilibrium, reduction of negative impact of human activity on the natural environment, decrease or limitation of the volumes of consumption of materials and energy sources.

\section{CONCLUSIONS}

In the EU countries, the innovative construction programs and projects of development of urban areas based on the so-called «biosphere compatibility» are gradually being developed. The key strategic determinants of those programs and projects are: 
- organization of construction on fundamentally innovative principles that in the priority are aimed at formation of safe (and favorable for selfdevelopment) human life;

- support of the balance of the bio-, techno- and socio- spheres of urban areas;

- successful involvement of the authorities, institutional participants, construction organizations and target consumers in organization of the cycle «initiation-investment-construction-operation» of construction objects that are comfortably implemented o the existing ecosystem of the development territory (the parameters of which in the EU are the subject of increased attention).

In Germany and Japan, the tenderer (developer) who has submitted a tender with a proposition that includes solutions for the targeted dominants of biosphere compatibility of construction, gains a significant advantage over other competitors. In those countries, the biosphere compatibility leaves by priorities behind even the criterion of «profitability / rationality of cost estimates».

Under conditions of continuing slowdown in activation of the construction market, decrease of the number of construction projects to be prepared and implemented and respective decrease in the volumes of construction and special works, there is a systemic trajectory of movement of organization of the construction activity towards growth of the requirements of the leading project participants as to biosphere compatibility in real estate development as a main component of reliability and competitive ability of construction projects, one of the key requirements for their successful implementation - throughout the whole duration of the project life cycle.

In our country there are no effective mechanisms to enhance the motivation of construction participants to engage the principles of biosphere compatibility at development of architectural and construction solutions. This tendency generates contradicting requirements and evaluation criteria for projects dealing with development of new product sand services. Under such circumstances, innovative mechanisms for managing construction projects and programs based on modernization of the investmentconstruction cycle and the systems of organization of construction based on the principles of biosphere compatibility are of particular relevance. Implementation of those principles in the face of ongoing downturn in construction sector becomes an important factor in attracting investments for 
domestic construction activity from foreign partners that adhere to the basis of biosphere compatible construction and declare strategic intentions to invest in Ukrainian construction activity on the above principles.

Therefore, the transition to biosphere-compatible construction in Ukraine should be assessed as an important strategic perspective that will influence the reform of the content and architectural and structural, technical and organizational-technological standards of construction.

\section{REFERENCES}

1. «Зеленые» здания Украины. https://www.breeam.com/

2. Офіційний сайт компанії Life House Building. - Режим доступу: http://lhb.com.ua/

3. Офіційний сайт компанії Ecopan. - Режим доступу: https://ecopanua.com/

4. Orlovs'ka Y. Green investments' programs as an element of industry's international mpetitiveness (on example of construction industry) / Y. Orlovs'ka, O. Kvaktun, V. Chala, M. Vovk // Marketing and Management of Innovations. - 2017. - № 3, C. 366 - 377.

5. Визначення тривалості будівництва об'єктів: ДСТУ Б А.3.122:2013 / Мінрегіонбуд України. - Вид. офіц. - Чинний від 2014-01-01. - Київ, 2014. - 30 с. - (Національний стандарт України).

6. Организационно-технологическая и экономическая надежность в строительстве / В. Р. Млодецкий, Р. Б. Тян, В. В. Попова, А. А. Мартыш. - Днепропетровск : Наука и образование, 2013. - 193 с.

7. Большаков В. І. Фактори, що здійснюють визначальний вплив на показники ефективності організаційно-технологічних рішень будівництва доступного житла [Електронний ресурс] / В. І. Большаков, Т. С. Кравчуновська, С. П. Броневицький // Вісник Придніпровської державної академії будівництва та архітектури. - 2016. - № 5. C. 61-70. - Режим доступу: http://nbuv.gov.ua/UJRN/Vpabia_2016_5_10

8. Большаков В. І. Фактори, що здійснюють визначальний вплив на показники ефективності організаційно-технологічних рішень будівництва доступного житла [Електронний ресурс] / В. І. Большаков, Т. С. Кравчуновська, С. П. Броневицький // Вісник Придніпровської державної академії будівництва та архітектури. - 2016. - № 5. C. 61-70. - Режим доступу: http://nbuv.gov.ua/UJRN/Vpabia_2016_5_10

9.Стан реалізації ключових завдань Державного агентства 3 енергоефективності та енергозбереження України у 2015 році 
[Електронний ресурс]. - Режим доступу: http://saee.gov.ua/sites/default/ files/Presentation_2015.pdf

10. Про енергетичну ефективність будівель: Закон України від 1 липня 2019 року № 33 [Електронний ресурс]. - Режим доступу: https://zakon.rada.gov.ua/laws/show/2118-19

11. Про внесення змін до деяких законів України щодо забезпечення конкурентних умов виробництва електричної енергії з альтернативних джерел енергії: Закон України від 25 травня 2019 року № 2712-VIII [Електронний ресурс]. - Режим доступу: https://zakon.rada.gov.ua/laws/ show/2712-viii

12. Про оцінку впливу на довкілля: Закон України від 23 травня 2017 року № 29 [Електронний ресурс]. - Режим доступу: https: https://zakon.rada.gov.ua/laws/show/2059-19

13. Реалізовані проекти Державного агентства з енергоефективності та енергозбереження України [Електронний ресурс]. - Режим доступу: http://saee.gov.ua/uk/business/realizovaniproekty

14. Повноваження Комітетів Будівельної палати України [Електронний pecypc]. - Режим доступу: http://budpalata.com.ua/ category/povnovagenya-komitets

\section{Information about the author:} Chernyshev D.,

DSc (Eng.), Associate Professor, First Vice-Rector, Kyiv National University of Construction and Architecture 31, Povitroflotsky Ave., Kyiv, 03037, Ukraine 